\title{
Effects of the Internalization of Peer-Modeled Self-efficacy on Coping with L2 Communication Stress
}

Jennifer Claro, Kitami Institute of Technology

https://orcid.org/0000-0003-4668-7242

claro1@mail.kitami-it.ac.jp

\begin{abstract}
This mixed-methods study explores the self-regulation of two Japanese university students in response to the stressful situation of feeling unable to communicate effectively in English with foreigners. Qualitative data from interviews are used to interpret the quantitative results of the two students, who were part of an online intercultural Japan-Canada university exchange in which half of the communication was in English. Due to the reality check of using English for communication with foreigners, both students realized that their English communication skills were weak. Self-efficacy and coping strategies modeled by peers were internalized by one student who could subsequently cope with the demands of interacting in English, and who developed a challenge orientation and set a new goal as a result. The other student became demotivated and withdrew over time. Theories related to stress and coping, self-efficacy, peer modeling, internalization, self-regulation, and possible selves are incorporated to provide a multidimensional view of the processes involved in the self-regulation of these students. By looking at the experiences of the two students at the individual level, insight may be gained into the reasons behind student engagement in and withdrawal from L2 learning processes. In particular, the importance of peer modeling to positive changes in student actual and ideal selves is examined.
\end{abstract}

Keywords: peer modeling, self-efficacy, coping strategies, self-regulation, internalization, possible selves 


\section{INTRODUCTION}

Shortly into a Japan-Canada online intercultural exchange, two students experienced a reality check: communicating in English with foreigners was difficult for them. Yet communicating in English using all four language skills was required in the interaction that took place in online forums as part of the project, and thus their low level of English ability was a source of stress for them. The way these two students reacted to their problem was very different. Despite having had high motivation at the beginning of the project, Taka decreased effort, gave up over time, and eventually withdrew from the project. In contrast, Hana, who had had a moderate level of motivation at the beginning of the project, increased effort, completed the project with higher motivation than when she started, and eventually set a new goal of living and working abroad. The main reasons for Hana's changes were effective self-regulation and the internalization of L2 communication self-efficacy and of coping strategies, after seeing these resources modeled by her peers.

These topics have not been previously explored within the field of L2 motivation. The relevance of self-efficacy to L2 acquisition and/or motivation has been described in some L2 research articles (see, e.g. Dörnyei, 1998; Mills, 2014; Mills et al., 2006; Oxford \& Shearin, 1994; Tseng et al., 2017). These studies have pointed to self-efficacy as a potential key construct in L2 research but have also pointed to the dearth of studies on self-efficacy in these fields (see Appendix A for descriptions of self-confidence and anxiety measures used in L2 motivation studies). In addition to selfefficacy, Dörnyei (1998), Oxford (2016), Tremblay and Gardner (1995) and some others have pointed to the importance of self-regulation and goal-setting to language learners, but L2 research studies detailing these processes are rare.

In the field of L2 motivation, stress evaluations, the effects of peer-modeled self-efficacy on stress evaluations, and subsequent motivation and performance have not been studied, and it is this gap in the literature that motivates the present study. As noted by Salas et al. (1996), theoretical and practical interest in how individuals perform in demanding, stressful environments is likely to continue to grow. Research into this area may be of interest to L2 motivation researchers, to researchers in the areas of stress, resilience and coping strategies, as well as to language teachers interested in stress in L2 communication and how to possibly mitigate it.

The purpose of this study is to contribute to and expand the knowledge base of L2 motivation research by describing the self-regulation of two Japanese university students dealing with the stressful activity of communicating in English with foreigners. This study explores the link between self-efficacy and stress, and how peer-modeled self-efficacy can change student evaluation of L2 communication stress from a threat to a challenge. I first explore the literature related to self-efficacy as a personal resource linked to positive outcomes in many areas of life, including academic performance and persistence. Modeled self-efficacy is described in the context of one study by Bandura et al. (1982), and then Lazarus and Folkman's (1984) transactional theory of stress and coping is explained. Challenge vs. threat evaluations of stress and the role of self-efficacy in these evaluations is the next focus, and here I explore how self-efficacy contributes to challenge evaluations, and how these evaluations are connected to better performance. Links between possible selves, selfefficacy, and self-regulation follow in the next section, and Higgins' $(1997,1998)$ promotional form of self-regulation is explained in brief before the study description. In the results section, quantitative results are examined first, and then the experiences of the two students are explored in detail, with interview data supporting and helping to explain the quantitative results. How peer models may act as resources for their classmates, modeling positive attitudes and useful strategies, and the effect that this has on classmate self-efficacy and performance is examined. Following the results and conclusion, pedagogical aspects of the study are briefly explored.

\section{LITERATURE REVIEW}

\section{Self-efficacy}

Self-efficacy has been defined simply by Bandura (1997) as the exercise of control, or, in more detail, as "beliefs in one's capabilities to mobilize the motivation, cognitive resources, and courses of action needed to meet given 
situational demands" (Wood \& Bandura, 1989, p. 408), for example, the belief that one is able to communicate effectively in another language. Self-efficacy is related to human agency and feeling a sense of control over our environment and events that affect our lives. Self-efficacy is directly linked to motivation: according to Bandura, selfefficacy beliefs determine an individual's level of motivation, including how much effort is exerted and how long they persevere when faced with obstacles. "The stronger the belief in their capabilities, the greater and more persistent are their efforts" (Bandura, 1989, p. 1176). Selfefficacy affects our well-being in many ways:

People with high assurance in their capabilities approach difficult tasks as challenges to be mastered rather than as threats to be avoided. Such an efficacious outlook fosters intrinsic interest and deep engrossment in activities. They set themselves challenging goals and maintain strong commitment to them. They heighten and sustain their efforts in the face of failure. They quickly recover their sense of efficacy after failures or setbacks. They attribute failure to insufficient effort or deficient knowledge and skills which are acquirable. They approach threatening situations with assurance that they can exercise control over them. Such an efficacious outlook produces personal accomplishments, reduces stress and lowers vulnerability to depression. (Bandura, 1994, p. 71)

Self-efficacy is linked to positive outcomes in many areas of life, including academic achievement. It influences self-regulatory processes such as goal setting, selfmonitoring, self-evaluation, and strategy use, and mediates the effect of personal attributes and assets such as level of skills, previous experience, cognitive ability, and other selfbeliefs on subsequent achievement (Schunk \& Pajares, 2005). A meta-analysis of research in educational settings (Multon et al., 1991) found that self-efficacy was related both to academic performance (effect size $=.38$ ) and to persistence (effect size $=.34$ ) across a wide variety of subjects, experimental designs, and assessment methods. Zajacova et al. (2005) found that self-efficacy was the single strongest predictor of grade point average (GPA) in all their tested models, and emphasized the importance of academic self-efficacy in predicting academic success in university and also in moderating the effect of stressors on perceived stress for university students.

In demanding situations, self-efficacy acts as an important personal resource that affects the perception of external demands and mediates the relation between external stressors and psychological stress (Bandura, 1995). General self-efficacy ${ }^{1}$ serves as a moderator for the impact of demands on the actual stress experience: individuals with high self-efficacy select positive cues, such as stable and favorable self-evaluations, over negative signals, such as situational failures, in making stress appraisals (Jerusalem \& Schwarzer, 1992, p. 210). Thus, the main effect of selfefficacy as a "key variable" (Karademas \& Kalantzi-Azizi, 2004) is to enable us to view the balance of stressor demands to coping resources (explained in an upcoming section) in a more positive way, and this enables us to evaluate demanding situations as challenges rather than threats (Chemers et al., 2001). The effect of self-efficacy on evaluations of a stressful situation as a challenge or threat is particularly intriguing.

\section{Modeled Self-efficacy}

Modeling is a main source of self-efficacy (Bandura, 1982, 1997). In lab experiments in which self-efficacy and coping techniques were explicitly modeled for the purpose of reducing fear of snakes in phobics, Bandura et al. (1982) found that fear arousal stemmed largely from perceived coping inefficacy. The modeling of feared activities from approaching to interacting with a boa constrictor resulted in a significant $14 \%$ rise in self-efficacy in subjects. For some participants, self-efficacy increased through modeling of snake handling alone, while for others, self-efficacy increased after modeling and subsequent mastery experiences over time. As the participants' self-efficacy level rose, they experienced progressively less stress while coping with a serious threat.

\section{The Transactional Theory of Stress and Coping}

According to Lazarus and Folkman's (1984) transactional theory of stress and coping, when individuals are faced with a stressful but self-relevant ${ }^{2}$ situation, they first appraise or 
evaluate $^{3}$ the balance of stressor demands (primary appraisal) to personal coping resources (secondary appraisal). After appraisal, people try to cope with the situation in three main ways, the first two originating in the work of Lazarus and Folkman (1984). Summarized by Amnie (2018) and Elliott et al. (2013), these are:

1. Problem-focused coping (adaptive): The individual attempts to discover and resolve the root cause of the stressors.

2. Emotion-focused coping (adaptive): The individual attempts to reduce a negative emotional state or change the appraisal of the demanding situation.

3. Avoidance coping (maladaptive): The individual tries to avoid the stressor. This form of coping was further developed by Kowalski and Crocker (2001), based on Amirkhan (1990) and Endler and Parker (1994).

In adaptive coping, people most often use a combination of problem- and emotion-focused coping to deal with stressful situations, but may use more or less of each depending on the situation (Folkman \& Lazarus, 1980). Situations in which the person thinks something constructive can be done or requires more information elicit problem-focused coping, whereas those that cannot be changed and therefore have to be accepted elicit emotionfocused coping.

\section{Effect of Challenge Evaluations on Performance}

If stressor demand exceeds coping resources, we perceive a threat because of the feeling of being unable to overcome the stressor. On the contrary, a belief that we can effectively cope with the stressor results in a challenge appraisal (Tomaka et al., 1993). Jones et al. (2009), investigating challenge and threat in athletes, point out that high selfefficacy is an important aspect of resource evaluations because an individual's "belief that she has the skills necessary to execute the courses of action required to succeed clearly contributes to a perception that she can cope with the demands of the situation" (p. 164). As we shall see, self-efficacy has a strong, positive link to challenge evaluations.

Challenge evaluations have been found to result in better performance than threat evaluations (e.g., Blascovich et al., 2004; Gildea et al., 2007; Jerusalem \& Schwarzer, 1992; Seery et al., 2010; Tomaka et al. 1993). In a longitudinal study of first-year university students, Chemers et al. (2001) used structural equation modeling to examine the effects of academic self-efficacy and optimism on students' academic performance, stress, health, and commitment to remain in school, and found that students with high self-efficacy had evaluations showing high challenge-to-threat ratios (i.e., they perceived academic task demands to be challenges rather than threats), and these resulted in greater academic expectations, which led to better academic performance. The effects of self-efficacy (and optimism) on stress, health, and adjustment variables in university students were entirely mediated by the challenge-threat variable (i.e., selfefficacy and optimism had no direct relationships to stress, health, or adjustment, they operated indirectly through challenge-threat). Chemers et al. concluded that challengethreat evaluations have a powerful impact on academic performance and other important outcomes including stress level and health of students.

As another example, Gildea et al. (2007) found that challenged participants outperformed threatened participants in video games that trained users in aviation skills. In their study, the challenge-threat variable predicted performance, while self-efficacy did not. However, selfefficacy was significantly correlated with secondary appraisals (resources, $r=.56, \mathrm{p}<.01$ ) but not primary appraisals (demand, $r=-.05$ ), indicating self-efficacy's contribution to a challenge evaluation.

To summarize, self-efficacy is a powerful personal resource that contributes to a wide range of positive outcomes from academic achievement to lower stress and better health. In stress evaluations, self-efficacy is a strong contributor to the appraisal of personal resources that contribute to a positive challenge-to-threat ratio, which is linked to better performance as well as good health. Jerusalem and Schwarzer (1992) wrote:

In the appraisal of challenge, a person may see an opportunity to prove herself or himself, anticipating 
gain, mastery or personal growth from the venture. The situation is experienced as pleasurable, exciting, and interesting, and the person is hopeful, eager, and confident to meet the demands. (p. 197)

Self-efficacy is a personal resource leading to positive outcomes that would seem to benefit all students, including language students. Believing that one is capable of doing what is required is essential for success in most, if not all, areas of life.

\section{Self-guides: Possible Selves and Self-regulation}

The importance of self-guides (ideal self and ought self) to the actual self and its development originated in Higgins' Self-Concept Discrepancy theory (Higgins 1987; Higgins et al., 1985). The actual self is a representation of the attributes that the individual believes they actually possess (or that others believe they possess). The ideal self is a representation of the attributes that the individual would ideally like to possess, while the ought self represents the attributes the individual thinks they ought to possess. Each self-guide has its own self-regulatory focus: promotion ${ }^{4}$ for the ideal self, concerned with advancement, growth, and accomplishment, and prevention for the ought self $f^{5}$, concerned with protection, safety and responsibility (Higgins, 1998). Higgins et al. (1985) pointed to the negative affect, felt as discomfort, that arises from discrepancy between one's actual self and one's ideal or ought self. For example, a discrepancy between one's actual self and one's ideal self results in feelings of dissatisfaction, disappointment, and fear of failure, in addition to "frustration-related emotions" (Higgins et al., 1985, p. 56).

Markus and Nurius (1986) used the term possible selves for ideal, ought, and feared selves and linked these to motivation. As Markus and Ruvolo (1989) explain:

Possible selves give specific, self-relevant form, meaning, and direction to one's hopes and threats. Possible selves are specific representations of one's self in future states and circumstances that serve to organize and energize one's actions. These thoughts, images, or senses of one's self in the end state and in the intermediate states... are viewed as the individualized carriers of motivation. They are the manifestations of one's goals, aspirations, motives, fears, and threats. (p. 212)

Possible selves have been linked by Markus and coauthors to self-efficacy and to self-regulation:

1. Self-efficacy: According to Markus and Nurius (1986, p. 961), self-efficacy is particularly influential when linked to "specific, clearly envisioned possible selves".

2. Self-regulation: Possible selves are personalized representations of goals. "The crucial element of a goal is the representation of the individual herself or himself approaching and realizing the goal. Without this representation of the self, a goal will not be an effective regulator of behavior" (Markus \& Ruvolo, 1989, p. 211).

The ideal self is a regulator of behavior when the individual believes that they are capable of achieving the goal. The ideal self must be specific and clearly envisioned, and must contain the element of oneself approaching and realizing the goal. Self-efficacy is essential because if you do not believe that you can adequately perform the skill, or cannot visualize how you will proceed in moving from actual to ideal, the goal will not be linked to behavior, and will not be realized. Bandura (1989, p. 1180) wrote that "the ability to envision likely outcomes of prospective actions" is known as an outcome expectation or expectancy and is one way in which "anticipatory mechanisms regulate human motivation and action." Outcome expectations are affected by one's level of self-efficacy. If an individual believes that they cannot do what it will take to achieve a particular outcome, it does not matter how appealing the outcome may be.

Dörnyei (2009) describes the experiential element of the ideal L2 self as what makes it more than just an abstract goal. "The imagery component of future self-guides is a powerful motivational tool" (p. 18). Students who want to live and work abroad may imagine life in a foreign country, meeting people, speaking their language, and it is this very positive (future) ideal L2 self that motivates them to make their dream a reality by studying the language, in the present. According to Markus and Ruvolo (1989, p. 213), "imagining one's own actions through the construction of 
elaborated possible selves achieving the desired goal may thus directly facilitate the translation of goals into intentions and instrumental actions". Oyserman et al. (2004, p. 132) agree: "possible selves and other self-directed goals can serve to guide and regulate behavior, providing a roadmap connecting the present to the future."

This article examines the experiences of the two students who had very different experiences in a university online intercultural exchange. Actual and ideal selves, stress and coping, self-efficacy and self-regulation all contributed to the reactions of these two students to a stressful situationspeaking English with foreigners.

\section{METHOD}

\section{Participants}

In my dissertation study (Claro, 2021), I measured student motivation as represented by intended learning effort (Dörnyei \& Taguchi, 2010) before and after an online intercultural exchange called the ICE Project (see below). Data were collected from 17 Japanese university students who gave informed consent to use their data and who also consented to interviews (see Appendix B for data elicitation materials). Nine third-year students participated in addition to four first-year students and four second-year students who volunteered to join the project (for no course credit) to help balance the number of participants in the two classes.

The data of two of students appears in this article. These two students were selected because in their interviews, they said that at the beginning of the project they had experienced problems in their communication with foreigners that they believed were caused by their own weak English skills. These two students dealt with this problem in very different ways, and their self-regulation and the effects of it are the main focus of this article.

\section{Instrument}

All scales and items are part of Dörnyei and Taguchi's (2010) L2 Motivational Self System (L2MSS) instrument (Japanese version) and were measured pre-study and post- study (two months later) using a 6-point Likert scale, where the minimum score is 1 and the maximum score is 6 .

\section{Analysis}

All statistical tests were performed by IBM SPSS Statistics (Version 22). Interviews were semi-structured and were conducted in Japanese by the author, then translated by bilingual Japanese university staff.

\section{Context}

The ongoing International Cultural Experience Project, or ICE Project, has taken place five times since it began in 2012 , most recently in 2020. The project has the main goal of providing communication partners for students to practice their target language and learn about each other's cultures. Participants in a Canadian university second-year Japanese class have various majors while participants at a Japanese technical university are all engineering majors, nine of them taking a third-year English class.

Participants take part in the project as part of their coursework. Interaction in the online project takes place half of the time in English and the other half in Japanese and consists of making video posts, in which students record videos of themselves speaking while looking at a webcam, and posting these videos in a private Moodle website for their two partners in Canada (partner activity), who reply to them in their own video posts. Further interaction takes place in an all-participant text-based forum where all students in both classes exchange messages freely (for more details, see Claro \& Akai, 2017).

The following section describes the quantitative and qualitative results of two students who experienced sizeable changes in motivation over the course of the ICE Project.

\section{RESULTS}

Taka's Reality Check: "I was worse than I thought."

Taka $^{6}$ was a first-year student who volunteered to participate in this particular ICE Project for no credit, to 
help balance the number of participants. Taka started the ICE Project believing that he was making good effort to learn English (ILE $=4.75, z$-score $=1.27$, see Table 1). Raw scores in Table 1 were standardized for the sake of easier comparison. A standardized score (or $z$-score) shows how much higher or lower that particular student score is than the mean of all Japanese student participant scores. A positive $z$-score of 1.0 indicates that the student score is one standard deviation above the mean, and a negative $z$-score of -1.0 indicates that the student score is one standard deviation below the mean. For the sake of comparison, I am using the simple heuristic of a difference of one standard deviation (or close to one) from $\mathrm{T} 1$ to $\mathrm{T} 2$ to indicate a notable change, and a difference of two standard deviations (or close to two) to indicate a large change.

Table 1. Raw Scores and Standardized Scores (z-scores) of Two Students with Changes from T1 to T2

\begin{tabular}{|c|c|c|c|}
\hline Scale & Time & Hana & Taka \\
\hline \multirow[t]{3}{*}{ Intended Learning Effort } & ILE T1 & $3.75(-0.65)$ & $4.75 \quad(1.27)$ \\
\hline & ILE T2 & $(1.34)$ & $3.75(-0.61)$ \\
\hline & $\Delta \mathrm{ILE}$ & 1.50 & $-1.00(-1.88)$ \\
\hline \multirow[t]{3}{*}{ Ideal L2 Self } & Ideal T1 & $3.20(-0.71)$ & $3.20(-0.71)$ \\
\hline & Ideal T2 & $5.20 \quad(1.23)$ & $4.00(-0.18)$ \\
\hline & $\Delta$ Ideal & $2.00 \quad(1.94)$ & $0.80 \quad(0.53)$ \\
\hline \multirow[t]{3}{*}{ Instrumentality-Promotion } & Prom T1 & $4.00 \quad(-1.33)$ & $4.40(-0.65)$ \\
\hline & Prom T2 & $5.40 \quad(0.61)$ & $3.60(-1.57)$ \\
\hline & $\Delta$ Prom & $1.40 \quad(1.94)$ & $-0.80(-0.92)$ \\
\hline \multirow[t]{3}{*}{ Linguistic Self-Confidence } & LSC T1 & $3.50 \quad(-0.46)$ & $4.50(0.70)$ \\
\hline & LSC T2 & $4.50 \quad(0.42)$ & $4.00(-0.42)$ \\
\hline & $\Delta \mathrm{LSC}$ & $(0.88)$ & $-0.50(-1.12)$ \\
\hline \multirow{3}{*}{ Attitudes Toward Learning English } & ATLE T1 & $(0.27)$ & $5.00 \quad(0.65)$ \\
\hline & ATLE T2 & $5.00 \quad(0.74)$ & $4.00(-0.83)$ \\
\hline & $\triangle \mathrm{ATLE}$ & $(0.47)$ & $-1.00(-1.48)$ \\
\hline \multirow{3}{*}{ Interest in the English Language } & IEL T1 & $(0.64)$ & $5.00(0.64)$ \\
\hline & IEL T2 & $(0.91)$ & $4.00(-1.30)$ \\
\hline & $\Delta \mathrm{IEL}$ & $(0.27)$ & $-1.00(-1.94)$ \\
\hline \multirow{3}{*}{ Integrativeness } & Integ T1 & $5.00 \quad(-0.26)$ & $5.33 \quad(0.30)$ \\
\hline & Integ T2 & $(0.09)$ & $3.67(-1.04)$ \\
\hline & $\Delta$ Integ & $-0.33(0.35)$ & $-1.66(-1.34)$ \\
\hline
\end{tabular}

Note. $N=17$ (Japanese engineering majors). Only variables that showed a change of one standard deviation or more are shown. Values that increased or decreased by one standard deviation or more from T1 to T2 appear in boldface. For L2MSS scale descriptions, scale construction, and questionnaire, see Dörnyei \& Taguchi (2010).

Hana's ILE raw score at T1 was 3.75, barely above the midpoint of 3.5 , but at $\mathrm{T} 2$ it was 5.25 , with a $z$-score change of 1.99, indicating a large increase in Intended Learning Effort (ILE), the criterion measure representing motivation. 
Hana's Ideal L2 Self and Instrumentality- Promotion (hereafter Promotion) $z$-scores also increased by almost two points (1.94 each), indicating large increases. In addition, Hana's Linguistic Self-confidence $z$-score increased 0.88 from T1 to T2. Hana experienced many positive changes from $\mathrm{T} 1$ to $\mathrm{T} 2$.

In contrast, Taka's ILE raw score dropped by one point from 4.75 to 3.75 , with a corresponding $z$-score of -1.88 , indicating that a negative change took place from T1 to T2. Three of Taka's other scores also decreased: Attitudes Toward Learning English (ATLE), Interest in the English Language (IEL), and Integrativeness. Taka became demotivated $^{7}$ over the course of this study. Let us look first at Taka's experience in the ICE Project, and continue in the next section with Hana's experience.

In his interview, Taka said that he hoped that speaking English would make him look cool and give him confidence:

It is cool to be able to speak English... If you can speak English, you look intelligent. Being able to speak English would be great... I would become confident... Simply being able to speak English would change me. I would become cool. (Taka, interview excerpts)

Taka said that he admired Kayoko, a classmate who was participating in the ICE Project for the second time (as a volunteer) and who was very motivated to learn and use English. She was very outgoing and spoke English as often as possible. Taka also said that on an exchange trip to Taiwan, he had seen another classmate speaking English well with Taiwanese university students, and Taka admired him for that. Desire to be able to speak English well and his desire to be cool both contributed to his motivation at the beginning of the project. Taka's outcome expectations (he would look cool) were high. But the crucial ingredient here is the ability to speak English well enough to communicate with foreigners. Bandura (1989) has pointed out that outcome expectations do not have much independent effect on performance motivation when outcomes depend on the level of competence. Thus, Taka's motivation depended largely on his level of perceived self-efficacy in communication in English.
But Taka soon experienced communication problems in the project, resulting in a loss of confidence in his ability to communicate in English:

I had thought I could do better. I could speak less than I thought, not even easy English sentences... I was worse than I thought... I have zero confidence in speaking English now. (Taka, interview)

Taka became demotivated by his communication problems in the intercultural project. He had had great expectations, hoping that he would look cool speaking English in the project, but these hopes seem to have been unrealistic, given that he already knew that his English ability was insufficient for communication with foreigners when he was in Taiwan.

When I was in Taiwan, one of my friends spoke English for me when I couldn't understand, so I felt relieved. When he was not with me, I felt uneasy. (Taka, interview)

Taka's dream of looking cool speaking English seems to have been based more on wishful thinking than on real possibility. Wright and Masten (2005) note that positive future expectations and perceptions of personal competence are related to resilience, but only when these perceptions are realistic. Dörnyei and Ushioda (2011) have also noted the need for realistic expectations. Ideal self images need to be substantiated, "resulting in the curious mixed aura of imagination and reality that effective images share. This process requires honest and down-to-earth reality checks..." (p. 232, emphasis mine). Simply put, Taka had imagined or hoped that his English skills were better than they really were, and the reality check of the ICE Project caused him to realize that his actual self was far from his ideal.

However, it is important to note that Taka took no steps to improve his English. He did not respond to the reality check by increasing effort to learn English. When I asked him in his interview if he felt that he should study English, he answered, "I don't have much motivation to study English". Instead of engaging in problem-focused coping by increasing effort and trying to improve his English, Taka decreased effort and slowly dropped out of the project. Taka used an avoidant form of coping to solve his problem. 
In Taka's case, this may have been an adaptive solution. Taka had evaluated a threat: he did not have the resources to communicate effectively in English, and he did not expect future success in this, so he took steps to eliminate the threat. Taka lost motivation in the ICE Project and in English at the same time as his desire to get into a particular lab in the following year was increasing. An important part of self-regulation is knowing when to quit, when to stop using precious resources for an activity that seems unlikely to pay off. Effective self-regulation may consist of persisting on a task until completion, or disengaging from a course of action that is doomed for failure (Diefendorff \& Lord, 2008). Taka did not see any hope for the future regarding his English ability:

I am not good at English, and I am aware that I am not good at it. I can't imagine myself getting better. (Taka, interview)

Taka does not see a strong need for English in his future. In addition, as a volunteer in this project, he would not get course credit. He may have regretted joining the ICE Project because it took away from his study time. He seems to have been less invested in the project than other students.

I will have exams next week. I will focus on my exams. My grades are important. The laboratory I would like to be in is very popular and I need good grades to get in. (Taka, interview)

A goal is more likely to be abandoned when attaining the goal seems unlikely, when it requires a great deal of effort and resources, when failure would have negative effects, and when there are other activities that may produce better results (Bandura, 1997). In Taka's case, it seems that he abandoned the ICE Project, and English with it, for all of these reasons, and this may in fact have been a good decision.

However, Taka's dropping out does not seem to have been simply a choice made between two activities competing for his time. Taka had started out with high motivation, one of three students with the highest level of ILE (a raw score of 4.75) at T1. His scores for Intended Learning Effort, Attitudes Toward Learning English, Interest in the English Language, and Integrativeness all decreased (see Table 1). If Taka had simply chosen another more appealing focus of study, it's unlikely that his scores would have decreased so much. His attitudes, motivation, and emotions were strongly affected by the reality check of discovering that his ability to communicate in English was poor, and was not getting better.

We might wonder whether Taka's experience in the ICE Project was affected by his being a first-year student, and therefore not being as integrated into the class as the thirdyear students. This is certainly a possibility, but there were four first-year students and four second-year students who had a wide variety of experiences in the project, both positive and negative. The only other student in the project who had a large decrease in motivation was a third-year student. And one first-year student had a large increase in motivation for reasons similar to Hana's (see Claro, 2021 for details).

One additional interesting result was that Taka's ideal L2 self increased from 3.2 to 4.0. This is due to an increase in PSS (Professionally Successful Self, part of the Ideal L2 Self, see Taguchi, 2013). This is a curious result from someone whose overall motivation dropped. Still more curiously, in my dissertation study (Claro, 2021), one other student had a large drop in motivation and other scores, but also had a rise in PSS. A possible explanation is that some classmates in the project had planned to use English in their future jobs and this may have been an especially attractive aspect of using English and hard to give up, however unrealistic it was. It seems that Taka believes that he may be able to use English to become professionally successful. So, there may have been one positive outcome of Taka's participation in the ICE Project — as long as Taka decides to increase effort to learn English before he starts working.

\section{Hana's Outcome: "I wanted to challenge myself"}

Hana initially had a raw score of $3.75(z$-score $=-0.65)$ for ILE at T1, close to the midpoint of 3.5, but it increased to 5.25 at $\mathrm{T} 2(z$-score $=1.34)$ for an overall increase of 1.50 . Hana experienced a strong positive change in ILE, as indicated by the $\Delta \mathrm{ILE} z$-score of 1.99 . But at the beginning of the project, Hana experienced a reality check similar to Taka's.

It was so difficult to write what I wanted to say. That English wasn't difficult at all, but I could not even 
tell them even easy things in English, so I was frustrated. It made me realize that I had to study English and keep studying English. (Hana, interview)

Hana's feeling of frustration is the effect of a discrepancy between her actual self and her ideal self (Higgins et al., 1985). Hana realized that she would have to work on her English if she wanted to be able to communicate well, so she increased effort and started studying English every day, at least until the time of her interview. Hana said that she was motivated by two classmates who were old-timers (students who had participated in the ICE Project at least once before, who had also had international travel experiences), Kayoko and Zen. Kayoko was a good friend of Hana's who "tries hard to do everything all the time." Hana was also motivated by one of her partners in Canada:

[I was motivated by] my partners, especially by Peter. He was cheerful and smiling and he was trying so hard to speak Japanese. So I decided to do my best too... In my own videos, I had been speaking English quietly with little confidence... My partner had a diligent, serious attitude so I decided to do my best in everything, like studying (not just English) and in my private life too. I thought his personality was great. I felt like I wanted to challenge myself in many different things. (Hana, interview)

Peter had a strong effect on Hana, who was impressed by his hard work to speak Japanese and by his positive, cheerful attitude. Hana also mentioned Zen and her senior classmates in her interview.

I met Zen in this class. When I first saw him speak English, I thought he was not good at speaking English. But he always challenged himself to do his best. I thought his attitude was amazing. I was always disappointed in myself when I could not do well. But my classmates were trying hard all the time, without becoming discouraged. I thought they were great. (Hana, interview)

It is important to note here that what was being modeled by Hana's peer models was not specifically their L2 ability. Hana did not mention how great anyone's English (or
Japanese) was. Instead, it was their attitude of trying hard to communicate in their limited English without becoming discouraged that Hana identified with. She wanted to be like her peer models, not because they were particularly good at a foreign language but because even at times of difficulty, they persevered. What was being modeled by Hana's peers was resilience. According to Bandura (1997, p. 88), "Undaunted attitudes exhibited by perseverant models as they cope with obstacles repeatedly thrown in their path can be more enabling to others than the particular skills being modeled." Bandura (1995) also noted that a resilient sense of efficacy is needed for the development of self-regulatory capabilities, and this requires resilience-building experiences, where perseverant effort is used to overcome obstacles. It is this perseverant effort that Hana saw in her peers and wanted for herself.

\section{Hana's Self-regulation}

According to Oyserman et al. (2004), the main difference between those who increase their effort in the face of difficulties and those who do not is whether self-regulatory mechanisms for reducing an actual-ideal discrepancy (Higgins, 1996) are triggered or not. For Hana, this discrepancy was triggered by the reality check of the ICE Project, where she found that she had problems communicating in English.

Instead of giving up over time like Taka did, Hana took action to attempt to fix the problems she was having. First, and perhaps most importantly, Hana compared herself to her classmates and noticed several discrepancies. In selfcomparison, she found that she was not working as hard as classmates she admired, so there was a discrepancy in effort. In response, Hana decided to study English every day.

[Now], even if I read or write just a little English every day, I try to do it. The driving force or energy was the ICE Project. Many juniors [younger students], students of the same age, and seniors too were working very hard and studying English, so I thought that my own study was not enough. (Hana, interview)

A major problem for Hana, and for most Japanese students in the project, was her low level of English ability. 
Therefore, trying to improve her English level by studying English seems like an appropriate response. This is a problem-focused form of coping where the individual attempts to discover and resolve the root cause of the stressors.

There were also differences in attitude: her peer models (Peter, Kayoko, and Zen) did not complain and tried hard to communicate with their limited language skills. They did not become discouraged and seemed not to be afraid of failure. As resilient language learners, they just kept trying. Hana identified with her resilient classmates: she wanted to be like them. She saw her Japanese classmates speaking English with each other as part of their usual English class activities, and also in the ICE Project, where they recorded many videos of themselves speaking English to their partners in Canada. She noticed that two attitudes in particular were a big help to her peer models: trying hard and not fearing failure, where failure meant making mistakes, not understanding, not communicating well in English. It was by trying hard and not being afraid of failure that her more capable classmates could communicate in their limited English. Hana internalized these attitudes and said in her interview, "If I too could try hard without being afraid of failure, I would be okay, I thought." She mentioned both of these attitudes several times in her interview, often accompanied by the words "brave" and "challenge."

Trying hard and not fearing failure are coping strategies. A coping strategy can be defined as "the situational use of a technique to reduce external demands or improve internal resources in dealing with an event perceived as stressful or unpleasant" (Anshel, 2012). By observing these coping strategies modeled by her peers, Hana could see the result, or outcome, of using them. This observational learning (Bandura, 1986, 1997; Bandura et al., 1966) aids in the formation of outcome expectations, or "beliefs about the outcomes of one's actions" (Schunk et al, 1987). Effective coping strategies can mitigate stress caused by a demanding situation, and this is what was modeled by Hana's peers. Hana saw resilient, adaptive attitudinal resources in her peer models and actively internalized them for her own use. Active internalization is the process that occurs when an individual sees a useful or attractive attribute or resource in someone else and internalizes it (see Claro, 2020) for their own use.
Internalized attributes may appear in the actual self immediately, i.e. as something an individual can do right away, as in the case of a change in attitude that affects one's behavior, for example, the immediate increase in selfefficacy by some individuals who had seen peer models handling snakes (Bandura et al., 1982). Or they may appear in one's behavior over time, as in the case of desire for a skill, such as English language ability. In Hana's case, the coping strategies of trying hard and not fearing failure appeared in her own behavior shortly after she internalized them, indicating that they had already become part of her actual self, but improving her English and working overseas are long-term goals that will take time to achieve. As such, these goals became part of her ideal L2 self, and this is reflected in the growth of Hana's ideal L2 self from 3.20 to 5.20 (out of a maximum score of 6.00). Her desire to become her new vision of herself in the future will fuel her efforts to learn English.

The construction of an ideal self originates in identification with role models (Claro, 2020; Flum, 2001; Gibson, 2004). In a role model, we see attractive attributes of a possible self, such as resilience, or maintaining a positive attitude. When an individual believes that having the modeled attribute would be advantageous, the ideal self may expand to take in new growth goals, as well as modeled strategies for how to get there. The ideal self in itself is a goal, a goal of becoming a better person, an improvement on the actual self. As a particularly clear and detailed goal, regularly visualized and anticipated, the ideal self regulates behavior towards achieving that goal, such as an increase in effort. Motivation comes from desire to close the discrepancy between the actual self and the ideal self, and thus achieve the goal of becoming one's ideal self. According to Higgins (1998), self-regulation is how we get from where we are (actual self) to where we want to be (ideal self).

The process of self-regulation is greatly facilitated by role models who may exemplify one's possible future self. When we see a peer role model doing things that we cannot, our own self-efficacy beliefs may rise, as we come to believe that if they can do that, we can too, given enough effort. "Learners compare themselves with their potential future selves and become excited (motivated) about that potential" (Murphey \& Arao, 2001, p. 1). Murphey and Arao coined the term near peer role models, to describe 
"peers who are close to one's social, professional, and/or age level, and who one may respect and admire". Schunk (1987) and others (e.g. Bandura, 1997; Sagotsky \& Lepper, 1982; Schunk \& Zimmerman, 1996) have used the term peer models and this seems appropriate for situations where peers are both near and far. Hana's peer models in Japan and in Canada were living examples of what she could become, if she worked hard as they did, and used their coping strategies in times of difficulty.

\section{Hana's Self-expansion}

Hana described how her experiences in the ICE Project affected her future vision of herself, her expanded ideal L2 self:

Before the ICE project, I was not so brave... I had a feeling that I wanted to travel to various countries, to see what it's like, but during the ICE Project I realized that this would not happen unless I became brave and decided to try hard... Before the ICE project, I used to make excuses to myself about why I didn't improve my English, like I'm too busy, or I did not have to because I had no goal. (Hana, interview)

Prior to the ICE Project, Hana did not have language learning goals, so she did not feel like she needed to improve her English. She had no commitment to learning English. She also did not know how good her own English was. Prior to a reality check, students who have had limited or no contact with foreigners have only vague ideas of how well they would be able to communicate in English, given the chance.

Post-project, Hana had a clear understanding of her English communication ability (see Figure 1 in Appendix C). She was able to understand what she was capable of by using her newfound resources in mastery experiences of communicating in English effectively with foreigners. She also knows how she will use English in the future. It is this clear vision of oneself in the future doing valued activities that strengthens the ideal self and gives it motivational power:
What I do is up to me. Now, I have a new goal, and I'll need English skill, so I decided to do my best... (Hana, interview)

And I imagine that working with using English is not easy, but it looks so exciting for me... I will surely make that a success, in my future. (Excerpt from Hana's essay at the end of the project, in her own English)

Here we see the importance of Hana's ideal self: she envisions herself using English in her future job and imagines the excitement that she will feel when she is able to do this. According to Markus and Ruvolo (1989), the crucial element of her goal is Hana's representation of herself realizing the goal, and it is this element that facilitates goal-regulating behavior. We also see the core elements of effective self-regulation: Hana has a new goal, and to achieve this goal, she needs English, so she needs to work hard. Her new goal is living and working overseas, a goal that she set towards the end of the ICE Project, and she has made a commitment to it:

This is a really big deal, but what I've been thinking about recently is that I want to work outside of Japan in the future... I used to study English simply because it was fun, but now I have a strong feeling that I have to work hard on my English so I can do many kinds of things in the future. (Hana, interview)

As summarized by Locke and Latham (2013), Bandura's (1986) social cognitive theory posits three variables that regulate behavior:

1. Goal setting;

2. Outcome expectancies regarding the outcome one can expect from one's performance (e.g., goal attainment/non-attainment); and,

3. Most importantly, self-efficacy, that is, one's confidence that one can do what is required to perform a given task. (p. 11)

Hana's self-regulation includes all three of these. Hana's self-efficacy, her belief that she can communicate in English, rose a great deal. Her outcome expectancies are positive: she believes that if she studies English and tries hard to speak English, her English will improve over time. 
Setting a goal of living and working overseas seems to be contingent on self-efficacy and outcome expectations: if Hana did not believe that she could communicate in English with foreigners, and did not expect that her ability would improve over time, it is unlikely that she would invest the time and effort needed to achieve this difficult goal. In fact, looking back at Taka's experience, it seems that he had low levels of all three of these self-regulation variables.

In adopting her new goal, Hana's ideal L2 self expanded by two full points. Hana set herself a challenge and proactively created a discrepancy (Bandura, 1991) between her actual self and her ideal self that she will have to work hard to reduce. There is a big gap between Hana's actual self and her ideal self, and closing this gap represents a major challenge to her. It is largely due to an increase in her personal resources (self-efficacy, coping strategies) that she is able to set herself this new challenge. According to Bandura (2013):

People motivate and guide themselves through proactive control by setting themselves challenging goals and performance standards that create negative discrepancies to be mastered. Reactive feedback control comes into play in the motivation and resources needed to realize the challenging goals. After people attain the goals they have been pursuing, those with high selfefficacy set a higher standard for themselves (Bandura $\&$ Cervone, 1986). The adoption of further challenges creates new motivating discrepancies to be mastered. (p. 149)

In an effort to reduce this new proactive discrepancy that she herself had created by setting a new goal, Hana increased effort to learn English by 1.50 points. This is via the promotion form of self-regulation, which increased by 1.40 points. Hana plans to achieve her goal by studying English daily, trying hard to communicate in her limited English without fearing failure, and asking for help when she needs it. All of these are proactive, promotional forms of self-regulation, concerned with "advancement, growth, and accomplishment" (Higgins, 1998, p. 37) that move Hana towards her ideal self.

According to Higgins, who created the concept of promotion (Higgins, 1997) as a form of self-regulation (not as a form of instrumental motivation), promotion has an ideal self-guide as goal (or standard). We can envision promotion as self-regulation including perseverant effort and coping strategies that move us from an actual self toward an ideal self (see Figure 2).

Hana's ideal L2 self expanded, and her self-regulation (promotion form) and effort to learn English both increased in Hana's attempt to achieve her new goal of living and working abroad.

Figure 2. Self-regulation from Actual Self to Ideal Self

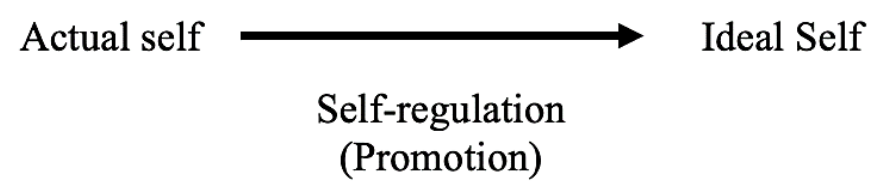

It is important to note that Hana's future goals of living and working abroad are realistic. She knows that she has to improve her English before she leaves Japan. And she knows that there is no guarantee that English skill alone will get her to a new life overseas. In her interview, she said, "Of course, even if I study English like this, I may not be able to achieve it and I may fail." But the main point is that Hana no longer fears failure as she used to, and she realizes that the way to achieve her goals is by challenging herself:

My confidence in my English ability did not change much. But before the ICE Project, I did not feel good about trying to do something I couldn't do and failing. But during this project, I thought that if I do not challenge myself, nothing will change. Now, I don't dislike challenging myself. I must do my best. (Hana, interview)

\section{DISCUSSION}

As mentioned in the literature review, modeling is a main source of self-efficacy (Bandura, 1982, 1997). In the Bandura et al. (1982) snake study, fear arousal was found to originate in perceived coping inefficacy. The modeling of coping with feared activities resulted in a significant rise in self-efficacy in subjects. 
We also saw that according to the transactional theory of stress and coping, greater perceived demand stress than personal resources results in a threat evaluation. In Figure 3, we can see that active internalization of self-efficacy results in an increase of resources. When personal resources exceed stress demand, the evaluation changes from a threat to a challenge.

Figure 3. From Threat to Challenge: The Internalization of Self-efficacy

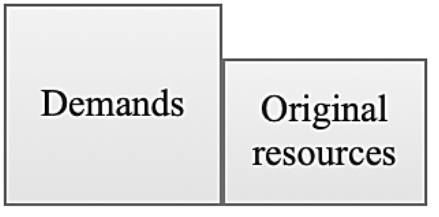

T1 Evaluation: Threat

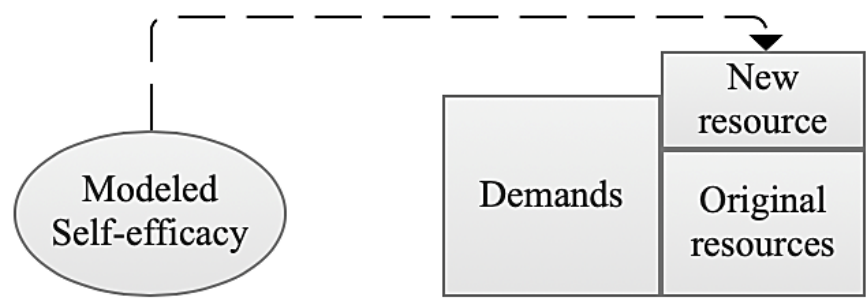

T2 Evaluation: Challenge
The snake experiment took place in a lab, but Hana's experience was natural, situated in an English class. The snake experiment used mastery models, who performed flawlessly from the start. But Hana's peers did not model a faultless performance; instead, they modeled struggling through a difficult and demanding situation, and are thus more appropriately termed coping models (Schunk, 1987). Coping models who gradually overcome difficulties through perseverant effort have been found to have greater impact than mastery models who demonstrate a faultless performance from the start (Kitsantas et al. 2000; Schunk \& Hanson, 1985; Schunk et al., 1987). Peer modeling of coping strategies is very useful for individuals who have had problems with performing the skill in the past and are unsure about their ability to perform well (Bandura, 1986; Schunk \& Hanson, 1985). Coping models may be most appropriate when threat is perceived (Schunk, 1987), as individuals may identify more with a fearful model, who overcomes their fear over time, than with a model who was never afraid. Meichenbaum (1971) found that the effect of coping models on fear reduction can be explained in part by perceived similarity of the model, as well as by the explicit modeling of coping strategies.

Self-efficacy was modeled by Hana's Japanese peers trying to speak English and by her Canadian partner struggling to speak Japanese. Hana's fear of failure was reduced by the modeling of self-efficacy, resilience, and coping techniques. Threat (linked to fear that she couldn't communicate in English) changed to challenge (linked to self-efficacy - she could communicate in English if she tried hard and didn't fear making mistakes) because of modeling by Hana's peers. Hana was able to internalize the self-efficacy and coping strategies that she saw modeled by her peer models, and this increased her personal resources to the point where speaking English represented a challenge rather than a threat.

Watching coping models persevere and succeed is an empowering experience. In coming to believe that if our peers can do it, we can too, we may become able to effectively deal with a stressful situation. Hana's fear of failure decreased, and her belief that she could communicate in English despite her limited ability grew. According to Bandura (1982):

It is mainly perceived inefficacy in coping with potentially aversive events that makes them fearsome. To the extent that one can prevent, terminate, or lessen the severity of aversive events, there is little reason to fear them. Hence experiences that increase coping efficacy can diminish fear arousal and increase commerce with what was previously dreaded and avoided. (p. 136) 
Table 2. Hana's Problem-focused Coping as Self-regulation

\begin{tabular}{|c|c|c|}
\hline Phase & Inner speech (hypothetical) & $\begin{array}{l}\text { Changes in self-efficacy and in } \\
\text { actual self }\end{array}$ \\
\hline $\begin{array}{l}\text { Actual self: } \\
\text { Pre-project }\end{array}$ & $\begin{array}{l}\text { I don't know if I can speak English well enough to } \\
\text { communicate. }\end{array}$ & \\
\hline Problem 1 & $\begin{array}{l}\text { l'm having problems communicating. } \\
\text { My English is not good enough. }\end{array}$ & \\
\hline $\begin{array}{l}\text { Problem solving: } \\
\text { Self-comparison }\end{array}$ & I wonder how other students do it. & \\
\hline $\begin{array}{l}\text { Selection of } \\
\text { peer models }\end{array}$ & $\begin{array}{l}\text { Those students seem to be able to communicate in } \\
\text { English, even though their English is not great. }\end{array}$ & \\
\hline $\begin{array}{l}\text { Observation of peer } \\
\text { models' strategies }\end{array}$ & $\begin{array}{l}\text { 1. They try hard to speak English. } \\
\text { 2. They seem not to fear failure. } \\
\text { 3. They study English in their free time. }\end{array}$ & \\
\hline Identification & $\begin{array}{l}\text { I want to be like them and be able to speak English } \\
\text { without fear like they can. }\end{array}$ & \\
\hline Internalization & $\begin{array}{l}\text { If they can do it, I can do it. } \\
\text { I will do as they do. }\end{array}$ & \\
\hline Behavioral changes & $\begin{array}{l}\text { 1. I will try hard to speak English. } \\
\text { 2. I will not fear failure. } \\
\text { 3. I will study English every day. }\end{array}$ & \\
\hline $\begin{array}{l}\text { Effect of } \\
\text { problem solving }\end{array}$ & $\begin{array}{l}\text { Mastery experience 1: } \\
\text { I can speak English if I use the coping strategies I } \\
\text { learned from my peers. }\end{array}$ & $\begin{array}{l}\text { 1. Increase in self-efficacy in } \\
\text { speaking English. } \\
\text { 2. Change in actual self: } \\
\text { I can speak English well enough to } \\
\text { communicate. }\end{array}$ \\
\hline Problem 2 & $\begin{array}{l}\text { Sometimes I have trouble understanding what my } \\
\text { partners in Canada say. }\end{array}$ & \\
\hline $\begin{array}{l}\text { Problem solving: } \\
\text { Behavioral change }\end{array}$ & When I can't understand, I will ask them to explain. & \\
\hline $\begin{array}{l}\text { Effect of } \\
\text { problem solving }\end{array}$ & They explain what they mean kindly and politely. & \\
\hline $\begin{array}{l}\text { Actual self: } \\
\text { Post-project }\end{array}$ & $\begin{array}{l}\text { Mastery experience 2: } \\
\text { I can communicate in English if I use the coping } \\
\text { strategies I learned from my peers, and the one I came } \\
\text { up with myself. }\end{array}$ & $\begin{array}{l}\text { 1. Increase in self-efficacy in } \\
\text { listening and understanding in } \\
\text { English. 2. Change in actual self: I } \\
\text { can understand English well } \\
\text { enough to communicate. }\end{array}$ \\
\hline
\end{tabular}


It is important to point out that Hana must be capable of using the coping strategies in order for her newfound selfefficacy to internalize well. An increase in perceived selfefficacy is mere wishful thinking if Hana cannot improve her performance by speaking English in front of peers without fear, as she saw her peers do. Hana needs mastery experiences to confirm that she can indeed use the new coping skills (Schunk \& Hanson, 1985). In this way, "I think I can do it if I do what they do" becomes "I can do it". It is when behavioral changes (in this case, using coping skills) result in improved performance (speaking English while trying hard and not fearing failure) that an increase in self-efficacy (she can do it) is realized. According to Schunk and Zimmerman (1996), "The belief that one knows what to do to perform a task raises self-efficacy, which is increased further as observers work on the task and experience success" (see also Schunk, 1989).

Hana was able to use the coping strategies she had learned, and found that she had solved one problem (fear of failure in speaking English) but that she had another problem to deal with - she could not understand what her Canadian partners meant sometimes. Hana solved this problem herself: "If I asked them about something I didn't understand, they explained it to me politely and kindly. Then I realized that I could communicate in this way" (Hana, interview, emphasis mine). Hana used both problemfocused and emotion-focused ways of coping with her English communication problems (see Table 2).

Hana could not solve all of her problems by problemfocused coping. She still has the problem of weak English skills, which will take time to improve. When the problem cannot be changed, or will take time to change, emotionfocused coping is helpful (Lazarus \& Folkman, 1984). Hana engaged in emotion-focused coping by adopting positive attitudes that she internalized from her peers. She no longer fears failure and is able to challenge herself. She has become similar to her peer models.

\section{CONCLUSION}

Perceived coping inefficacy is the main cause of fear in stressful situations (Bandura et al., 1982). Self-efficacy is a powerful, protective resource which contributes to adaptive coping. Modeled self-efficacy and other resources can be internalized and used by the individual: in some cases immediately, as part of one's actual self, in other cases later, as part of one's ideal self. In this article, we have seen the powerful effect of the peer modeling of self-efficacy on one student, Hana, who had moderate motivation to learn English prior to an intercultural online project. By observing her self-efficacious peers, who tried hard to speak English despite difficulty, Hana was able to internalize their L2 communication self-efficacy in addition to their resilience and coping strategies. As a result, Hana's personal resources increased and exceeded stressor demand, and Hana's evaluation of the task of communication in English developed into a challenge. Resolving her previous problems by using her new coping strategies of trying hard, not fearing failure, and asking for help when necessary, Hana realized that she could indeed communicate in English. With little discrepancy between her peers' performance and her own, her short-term goal of being able to communicate effectively in English was achieved. Hana then set herself a new long-term goal of living and working overseas, creating a proactive discrepancy between her actual and ideal selves. Achieving this goal will require strong English skills. At the time of the interview, Hana was still studying English every day and was planning to go to Norway on a university research exchange. As Oxford and Shearin (1994, p. 21) assert, "L2 learners with established goals and a sense of self-efficacy will focus on learning tasks, persist at them, and develop strategies to complete tasks successfully so they can meet their goals".

Taka experienced the same reality check that Hana did: his English level was insufficient for communication with foreigners. While Hana used problem-focused and emotionfocused coping, Taka dealt with this problem by using avoidance coping and dropping out of the ICE Project. Avoidance coping is often seen to be maladaptive, but when the individual perceives that nothing can be done about the situation, distancing oneself from the stressor may be adaptive (Folkman \& Moskowitz, 2004). Taka's selfefficacy in L2 communication ability was low, and he chose to invest his time and effort in another goal in which his outcome expectancies were higher. This seems to have been effective self-regulation for someone who did not perceive a strong need for English in his future. 
Hana may have been an exceptional student in that she made such active use of her peer models' strategies. The important point is that without peer models, identification and internalization cannot happen. Students need to see their peers trying hard and struggling to succeed, so they can be inspired by them, and also so they can see useful strategies for coping with the stress of communicating in English. Many students may perceive speaking English with foreigners to be a threatening situation; therefore, one way to deal with this would be to help students to increase their self-efficacy in L2 communication. Efficacious peers are resources. Teachers can help to change a threat to a challenge by providing experiences that create access to these efficacious peers, and these experiences may lead to increased coping efficacy. Projects like the ICE Project tend to attract motivated students who try hard to speak English, and these students may act as peer models for students who may be less motivated, or do not know how to struggle though a challenging English communication activity. Students who try hard and push themselves to persevere even in difficulty show students a possible future self, an alternate self, an appealing self. These students have valuable resources, and by modeling them, they share them with less resourceful students. This brings Vygotsky's (1978) zone of proximal development into this discussion, but we have time for only a brief nod now.

Many language students have not had the experience of using their L2 for real communication, but this is a vital experience. Teachers can provide this kind of experience for students by first creating supportive situations where students practice speaking English to communicate with each other. If possible, even better are international projects, or local projects with foreigners as participants. Activities in which students use English to communicate may be motivating, and are also very useful for the reality check they may provide. In performing a skill, we may sense a discrepancy between ourselves and others, or between ourselves and our own ideal self, and it is this discrepancy that may motivate us to take action to close the gap (Higgins et al., 1985; Higgins 1987, 1996; Markus \& Nurius, 1986; Markus \& Ruvolo, 1989).

One strength of this study is that the effects of peermodeled self-efficacy on stress evaluations and coping likely apply to contexts other than L2 communication. Self- efficacy is one of the most-studied concepts in motivational theory and has been studied in hundreds of contexts (see Bandura, 1997). Future studies could investigate the effects of peer-modeled self-efficacy on stress evaluations in various contexts. It seems probable that internalization of peer-modeled self-efficacy and coping mechanisms would boost personal resources and result in challenge evaluations by individuals engaged in many different areas of pursuit.

This study has two main limitations. By focusing on the experiences of only two students, the experiences of the other students have not been examined here (see Claro, 2021 for results related to experiences of other participants). It is possible that the experiences of these two particular students are unusual and may not be generalizable to the general population of L2 learners. More studies need to be done in order to confirm the importance of coping with stress in L2 communication, as well as the importance of peer-modeled self-efficacy, resilience, and coping abilities for L2 learners, the internalization of these resources, and the outcomes of internalization. Another limitation is that a self-efficacy scale was not used in this study. My dissertation study used the L2MSS instrument, which does not have measures of self-efficacy (nor a measure of L2 communicative competence, see Appendix C), resilience, or coping strategies. Quantitative data related to the reported qualitative results would help to support the conclusions reached in this article; thus, future studies in this area should include these scales.

Future studies should also consider analysis at the individual level to be a valuable form of data analysis. Only by looking at the experiences of students close up, and trying to explain the origins and effects of important changes in motivation at the individual level can we understand how to better support and facilitate experiences that lead to student growth in self-efficacy and resilience, leading to increases in performance and ability. Observation of self-regulatory processes during periods of change may lead to better understanding of what causes student engagement and motivation to learn as well as how students use strategies to achieve their goals. Study of the internalization of valuable resources modeled by peers may best be done by observation of individual experiences in peer groups engaged in real-life use of skills. 
${ }^{1}$ Self-efficacy was originally conceived by Bandura (1977) as a measure linked to a particular activity, such as self-efficacy with snakes, or with a specific kind of math problem. Later, researchers proposed general self-efficacy as "the belief in one's competence to tackle novel tasks and to cope with adversity in a broad range of stressful or challenging encounters, as opposed to specific selfefficacy, which is constrained to a particular task at hand" (Luszczynska, Gutiérrez-Doña \& Schwarzer, 2005).

2 Self-relevant: relevant to the way an individual perceives themselves now (actual self) or perceives a future self (possible self, ideal self).

${ }^{3}$ Pointing out that "the determining processes were often much less conscious than the label cognitive appraisal implies", Blascovich (2008) and some other researchers (e.g. Chemers et al., 2001; Seery, 2013) have used the label evaluation instead of appraisal.
${ }^{4}$ For articles linking challenge and threat to regulatory focus, see Keller (2007) and Sassenberg and Scholl (2019).

${ }^{5}$ In Claro (2016) and in my dissertation (2021), the ought-to L2 self did not have a significant correlation with intended learning effort (ILE, the criterion measure) for my sample population of Japanese university students, but the ideal L2 self did in both. Therefore, I focus on the ideal L2 self, as it appears to be a motivator for this population.

${ }^{6}$ All names are pseudonyms.

${ }^{7}$ Demotivation refers to a loss of motivation in response to negative influences and events, rather than a lack of motivation, which is termed amotivation (Dörnyei \& Ushioda, 2011).

\section{Acknowledgements}

I would like to thank Molly Wills, the editors, and one anonymous reviewer for their thoughtful comments on earlier versions of this manuscript.

\section{Author's Contributions}

There is only one author of this article. Jennifer Claro is responsible for all of the work done for this article.

\section{Ethics Approval \& Consent to Participate}

This article includes data collected in but not included in my dissertation (Claro, 2021) study, titled "Effects of an Online Intercultural Exchange on the Motivation of Japanese University Students to Learn English". My dissertation study was approved by the Ontario Institute for Studies in Education, University of Toronto Research Ethics Board (approval no. 30348). All participants provided written informed consent prior to enrolment and data collection in the study.

\section{Funding}

This article was written while the author was supported in part by a Grant-in-Aid for Scientific Research from the Japan Society for the Promotion of Science (grant no. 20K00769).

\section{REFERENCES}

Amirkhan, J. H. (1990). A factor analytically derived measure of coping: The Coping Strategy Indicator. Journal of Personality and Social Psychology, 59(5), 1066-1074. https://doi.org/10.1037/0022-3514.59.5.1066

Amnie, A. G. (2018). Emerging themes in coping with lifetime stress and implication for stress management education. SAGE Open Medicine, 6, 1-9. https://doi.org/10.1177/2050312118782545
Anshel, M. H. (2012). Coping with stress. In N.M. Seel (Ed.), Encyclopedia of the sciences of learning (pp. 818-822). Springer Science \& Business Media. https://doi.org/10.1007/978-1-4419-1428$\underline{6} 473$

Bandura, A. (1977). Self-efficacy: toward a unifying theory of behavioral change. Psychological Review, 84(2), 191-215. https://doi.org/10.1037/0033-295x.84.2.191 
Bandura, A. (1982). Self-efficacy mechanism in human agency. American Psychologist, 37(2), 122-147. https://doi.org/10.1037/0003-066x.37.2.122

Bandura, A. (1986). Social foundations of thought and action: A social cognitive theory. Prentice-Hall.

Bandura, A. (1989). Human agency in social cognitive theory. American Psychologist, 44(9), 1175-1184. https://doi.org/10.1037/0003-066x.44.9.1175

Bandura, A. (1991). Social cognitive theory of selfregulation. Organizational Behavior and Human Decision Processes, 50(2), 248-287. https://doi.org/10.1016/0749-5978(91)90022-1

Bandura, A. (1994). Self-efficacy. In V.S. Ramachaudran (Ed.), Encyclopedia of human behavior (vol. 4, pp. 71-81). Academic Press. (Reprinted in H. Friedman [Ed.], Encyclopedia of mental health. Academic Press, 1998). https://www.uky.edu/ eushe2/Bandura/BanEncy.h tml

Bandura, A. (1995). Exercise of personal and collective efficacy in changing societies. In A. Bandura (Ed.), Self-efficacy in changing societies (pp. 145). Cambridge University Press. https://doi.org/10.1017/cbo9780511527692.003

Bandura, A. (1997). Self-efficacy: The exercise of control. W. H. Freeman.

Bandura, A. (2006). Guide for constructing self-efficacy scales. Self-efficacy Beliefs of Adolescents, 5(1), 307-337.

Bandura, A. (2013). The role of self-efficacy in goal-based motivation. In E.A. Locke \& G.P. Latham (Eds.), Development in goal setting and task performance (pp. 147-157). Taylor \& Francis. https://doi.org/10.4324/9780203082744

Bandura, A., Grusec, J. E., \& Menlove, F. L. (1966). Observational learning as a function of symbolization and incentive set. Child Development, 37(3), 499-506. https://doi.org/10.2307/1126674
Bandura, A., Reese, L., \& Adams, N. E. (1982). Microanalysis of action and fear arousal as a function of differential levels of perceived selfefficacy. Journal of Personality and Social Psychology, 43(1), 5-21. https://doi.org/10.1037/0022-3514.43.1.5

Blascovich, J. (2008). Challenge and threat. In A.J. Elliot (Ed.), Handbook of approach and avoidance motivation (pp. 431-445). Psychology Press. https://doi.org/10.4324/9780203888148.ch25

Blascovich, J., Seery, M. D., Mugridge, C. A., Norris, R. K., \& Weisbuch, M. (2004). Predicting athletic performance from cardiovascular indexes of challenge and threat. Journal of Experimental Social Psychology, 40(5), 683-688. https://doi.org/10.1016/j.jesp.2003.10.007

Chemers, M. M., Hu, L. T., \& Garcia, B. F. (2001). Academic self-efficacy and first year college student performance and adjustment. Journal of Educational Psychology, 93(1), 55-64. https://doi.org/10.1037/0022-0663.93.1.55

Claro, J. (2016). Japanese first-year engineering students' motivation to learn English. Studies of Human Science, 12, 67-105.

https://www.researchgate.net/profile/JenniferClaro/research

Claro, J. (2020). Identification with external and internal referents: Integrativeness and the ideal L2 self. In P.D. MacIntyre \& A.H. Al-Hoorie (Eds.), Contemporary language motivation theory: 60 Years since Gardner and Lambert (1959) (pp. 233-261). Multilingual Matters.

Claro, J. (2021). Effects of an online intercultural exchange on the motivation of Japanese university students to learn English [Doctoral dissertation in preparation]. Ontario Institute for Studies in Education of the University of Toronto.

Claro, J., \& Akai, S. (2017). Collaborative reflection in an online intercultural Japan-Canada exchange. In P. Hubbard \& S. Ioannou-Georgiou (Eds.), Teaching English reflectively with technology (pp. 91-108). IATEFL. 
https://www.researchgate.net/profile/JenniferClaro/research

Clément, R., \& Kruidenier, B. G. (1985). Aptitude, attitude and motivation in second language proficiency: A test of Clément's model. Journal of Language and Social Psychology, 4(1), 21-37.

https://doi.org/10.1177/0261927x8500400102

Diefendorff, J. M., \& Lord, R. G. (2008). Goal-striving and self-regulation processes. In R. Kanfer, G. Chen, \& R.D. Pritchard (Eds.), Work motivation: Past, present, and future (pp. 151-196).

Routledge. https://doi.org/10.4324/9780203809501

Dörnyei, Z. (1998). Motivation in second and foreign language learning. Language Teaching, 31(3), 117-135. https://doi.org/10.1017/s026144480001315x

Dörnyei, Z. (2009). The L2 motivational self system. In Z. Dörnyei \& E. Ushioda (Eds.), Motivation, language identity and the L2 self (pp. 9-42). Multilingual Matters.

Dörnyei, Z., \& Taguchi, T. (2010). Questionnaires in second language research: Construction, administration, and processing. Routledge. https://doi.org/10.4324/9780203864739

Dörnyei, Z., \& Ushioda, E. (2011). Teaching and researching motivation. Pearson.

Elliott, D. C., Kaliski, P., Burrus, J., \& Roberts, R. D. (2013). Exploring adolescent resilience through the lens of core self-evaluations. In S. PrinceEmbury \& D. H. Saklofske (Eds.), Resilience in children, adolescents, and adults (pp. 199-212). Springer. https://doi.org/10.1007/978-1-46144939-3

Endler, N. S., \& Parker, J. D. (1994). Assessment of multidimensional coping: Task, emotion, and avoidance strategies. Psychological Assessment, 6(1), 50-60. https://doi.org/10.1037/1040$\underline{3590.6 .1 .50}$

Flum, H. (2001). Relational dimensions in career development. Journal of Vocational
Behavior, 59(1), 1-16.

https://doi.org/10.1006/jvbe.2000.1786

Folkman, S., \& Lazarus, R. S. (1980). An analysis of coping in a middle-aged community sample. Journal of Health and Social Behavior, 21, 219-239. https://doi.org/10.2307/2136617

Folkman, S., \& Moskowitz, J. T. (2004). Coping: Pitfalls and promise. Annual Review of Psychology, 55, 745-774.

https://doi.org/10.1146/annurev.psych.55.090902. $\underline{141456}$

Gibson, D. E. (2004). Role models in career development: New directions for theory and research. Journal of Vocational Behavior, 65(1), 134-156. https://doi.org/10.1016/s0001-8791(03)00051-4

Gildea, K. M., Schneider, T. R., \& Shebilske, W. L. (2007). Stress appraisals and training performance on a complex laboratory task. Human Factors, 49(4), 745-758. https://doi.org/10.1518/001872007x215818

Higgins, E. T. (1987). Self-discrepancy: a theory relating self and affect. Psychological Review, 94(3), 319340. https://doi.org/10.1037/0033-295x.94.3.319

Higgins, E. T. (1996). The "self digest": Self-knowledge serving self-regulatory functions. Journal of Personality and Social Psychology, 71(6), 10621083. https://doi.org/10.1037/0022$\underline{3514.71 .6 .1062}$

Higgins, E. T. (1997). Beyond pleasure and pain. American Psychologist, 52(12), 1280-1300. https://doi.org/10.1037/0003-066x.52.12.1280

Higgins, E. T. (1998). Promotion and prevention: Regulatory focus as a motivational principle. Advances in Experimental Social Psychology, 30, 1-46. https://doi.org/10.1016/s00652601(08)60381-0

Higgins, E. T., Klein, R., \& Strauman, T. (1985). Selfconcept discrepancy theory: A psychological model for distinguishing among different aspects of depression and anxiety. Social Cognition, 3(1), 51-76. https://doi.org/10.1521/soco.1985.3.1.51 
Irie, K. (2005). Stability and flexibility of language learning motivation: A multimethod study of Japanese junior high school students. Temple University.

Jerusalem, M., \& Schwarzer, R. (1992). Self-efficacy as a resource factor in stress appraisal. In R. Schwarzer (Ed.), Self-efficacy: Thought control of action (pp. 195-216). Hemisphere.

Jones, M., Meijen, C., McCarthy, P. J., \& Sheffield, D. (2009). A theory of challenge and threat states in athletes. International Review of Sport and Exercise Psychology, 2(2), 161-180. https://doi.org/10.1080/17509840902829331

Karademas, E. C., \& Kalantzi-Azizi, A. (2004). The stress process, self-efficacy expectations, and psychological health. Personality and Individual Differences, 37(5), 1033-1043. https://doi.org/10.1016/j.paid.2003.11.012

Keller, J. (2007). When negative stereotypic expectancies turn into challenge or threat: The moderating role of regulatory focus. Swiss Journal of Psychology, 66(3), 163-168.

Kitsantas, A., Zimmerman, B. J., \& Cleary, T. (2000). The role of observation and emulation in the development of athletic self-regulation. Journal of Educational Psychology, 92(4), 811-817. https://doi.org/10.1037/0022-0663.92.4.811

Kowalski, K. C., \& Crocker, P. R. (2001). Development and validation of the Coping Function Questionnaire for adolescents in sport. Journal of Sport and Exercise Psychology, 23(2), 136-155. https://doi.org/10.1123/jsep.23.2.136

Lazarus, R. S., \& Folkman, S. (1984). Stress, appraisal, and coping. Springer.

Locke, E. A. \& Latham, G. P. (2013). Goal setting theory, 1990. In E.A. Locke and G.P. Latham (Eds.), New developments in goal setting and task performance (pp. 3-15). Routledge.

Luszczynska, A., Gutiérrez-Doña, B., \& Schwarzer, R. (2005). General self-efficacy in various domains of human functioning: Evidence from five countries. International Journal of

Psychology, 40(2), 80-89.

https://doi.org/10.1080/00207590444000041

Markus, H. R., \& Nurius, P. (1986). Possible selves. American Psychologist, 41(9), 954-969. https://doi.org/10.1037/0003-066x.41.9.954

Markus, H. R., \& Ruvolo, A. (1989). Possible selves: Personalized representations of goals. In L.A. Pervin (Ed.), Goal concepts in personality and social psychology (pp. 211-241). Lawrence Erlbaum. https://doi.org/10.4324/9781315717517

MacIntyre, P. D., \& Gardner, R. C. (1991). Methods and results in the study of anxiety and language learning: A review of the literature. Language Learning, 41(1), 85-117. https://doi.org/10.1111/j.14671770.1991.tb00677.x

Meichenbaum, D. H. (1971). Examination of model characteristics in reducing avoidance behavior. Journal of Personality and Social Psychology, 17(3), 298-307. https://doi.org/10.1037/h0030593

Mills, N. (2014). Self-efficacy in second language acquisition. In S. Mercer \& M. Williams (Eds.), Multiple perspectives on the self in SLA (pp. 622). Multilingual Matters.

Mills, N., Pajares, F., \& Herron, C. (2006). A reevaluation of the role of anxiety: Self-efficacy, anxiety, and their relation to reading and listening proficiency. Foreign Language Annals, 39(2), 276-295. https://doi.org/10.1111/j.19449720.2006.tb02266.x

Multon, K. D., Brown, S. D., \& Lent, R. W. (1991). Relation of self-efficacy beliefs to academic outcomes: A meta-analytic investigation. Journal of Counseling Psychology, 38(1), 30-38. https://doi.org/10.1037/0022-0167.38.1.30

Murphey, T., \& Arao, H. (2001). Reported belief changes through near peer role modeling. TESL-EJ, 5(3), $1-15$. 
Oxford, R. L. (2016). Teaching and researching language learning strategies: Self-regulation in context. Routledge.

Oxford, R., \& Shearin, J. (1994). Language learning motivation: Expanding the theoretical framework. The Modern Language Journal, 78(1), 12-28. https://doi.org/10.1111/j.15404781.1994.tb02011.x

Oyserman, D., Bybee, D., Terry, K., \& Hart-Johnson, T. (2004). Possible selves as roadmaps. Journal of Research in Personality, 38(2), 130-149. https://doi.org/10.1016/s0092-6566(03)00057-6

Sagotsky, G., \& Lepper, M. R. (1982). Generalization of changes in children's preferences for easy or difficult goals induced through peer modeling. Child Development, 53(2), 372-375. https://doi.org/10.2307/1128978

Salas, E., Driskell, J. E., \& Hughes, S. (1996). Introduction: The study of stress and human performance. In J.E. Driskell \& E. Salas (Eds.), Stress and human performance (pp. 1-45). Lawrence Erlbaum Associates, Inc.

Sassenberg, K., \& Scholl, A. (2019). Linking regulatory focus and threat-challenge: Transitions between and outcomes of four motivational states. European Review of Social Psychology, 30(1), 174-215. https://doi.org/10.1080/10463283.2019.1647507

Schunk, D. H. (1987). Peer models and children's behavioral change. Review of Educational Research, 57(2), 149-174. https://doi.org/10.3102/00346543057002149

Schunk, D. H. (1989). Self-efficacy and achievement behaviors. Educational Psychology Review, 1(3), 173-208. https://doi.org/10.1007/bf01320134

Schunk, D. H., \& Hanson, A. R. (1985). Peer models: Influence on children's self-efficacy and achievement. Journal of Educational Psychology, 77(3), 313-322. https://doi.org/10.1037/0022-0663.77.3.313
Schunk, D. H., Hanson, A. R., \& Cox, P. D. (1987). Peermodel attributes and children's achievement behaviors. Journal of Educational Psychology, 79(1), 54-61. https://doi.org/10.1037/0022-0663.79.1.54

Schunk, D. H., \& Pajares, F. (2005). Competence perceptions and academic functioning. In A.J. Elliot \& C.S. Dweck (Eds.), Handbook of competence and motivation (pp. 85-104). Guilford Press.

Schunk, D. H., \& Zimmerman, B. J. (1996). Modeling and self-efficacy influences on children's development and self-regulation. In J. Juvonen \& K. Wentzel (Eds.), Social motivation: Understanding children's school adjustment (pp. 154-180). Cambridge University Press. https://doi.org/10.1017/cbo9780511571190.009

Seery, M. D. (2013). The biopsychosocial model of challenge and threat: Using the heart to measure the mind. Social and Personality Psychology Compass, 7(9), 637-653. https://doi.org/10.1111/spc3.12052

Seery, M. D., Weisbuch, M., Hetenyi, M. A., \& Blascovich, J. (2010). Cardiovascular measures independently predict performance in a university course. Psychophysiology, 47(3), 535-539. https://doi.org/10.1111/j.1469-8986.2009.00945.x

Taguchi, N. (2013). Motivation, attitudes and selves in the Japanese context: A mixed methods approach. In M.T. Apple, D. Da Silva, \& T. Fellner (Eds.), Language learning motivation in Japan (pp. 169188). Multilingual Matters.

Tomaka, J., Blascovich, J., Kelsey, R. M., \& Leitten, C. L. (1993). Subjective, physiological, and behavioral effects of threat and challenge appraisal. Journal of Personality and Social Psychology, 65(2), 248260. https://doi.org/10.1037/0022-3514.65.2.248

Tremblay, P. F., \& Gardner, R. C. (1995). Expanding the motivation construct in language learning. The Modern Language Journal, 79(4), 505-518. https://doi.org/10.1111/j.15404781.1995.tb05451.x 
Tseng, W. T., Liu, H., \& Nix, J. M. L. (2017). Selfregulation in language learning: Scale validation and gender effects. Perceptual and Motor Skills, 124(2), 531-548. https://doi.org/10.1177/0031512516684293

Vygotsky, L. S. (1978). Mind in society: The development of higher psychological processes. Harvard University Press. https://doi.org/10.2307/j.ctvjf9vz4

Wright, M. O., \& Masten, A. S. (2005). Resilience processes in development: Fostering positive adaptation in the context of adversity. In S.
Goldstein \& R.B. Brooks (Eds.), Handbook of resilience in children (pp. 17-37). Springer.

Wood, R., \& Bandura, A. (1989). Impact of conceptions of ability on self-regulatory mechanisms and complex decision making. Journal of Personality and Social Psychology, 56(3), 407-415. https://doi.org/10.1037/0022-3514.56.3.407

Zajacova, A., Lynch, S. M., \& Espenshade, T. J. (2005). Self-efficacy, stress, and academic success in college. Research in Higher Education, 46(6), 677-706. https://doi.org/10.1007/s11162-004$\underline{4139-z}$

\section{APPENDICES}

\section{Appendix A: Self-confidence and Anxiety in L2 Motivation Studies}

In the field of L2 motivation, Dörnyei and Taguchi's (2010) linguistic self-confidence measure used in this study as part of the L2MSS instrument is quite different from Bandura's concept of self-efficacy. As a measure of confidence in one's future ability in reading and writing English, three of the four items in Dörnyei and Taguchi's (2010) scale contain the word will. Bandura says in his scale construction guide (2006, pp. 308-309), "Self-efficacy is concerned with perceived capability. The items should be phrased in terms of can do rather than will do [emphasis in original]. Can is a judgment of capability; will is a statement of intention. Perceived self-efficacy is a major determinant of intention, but the two constructs are conceptually and empirically separable". Thus, we cannot use the L2MSS version of linguistic self-confidence as a measure of self-efficacy, although it is possible that there is a correlation between these two measures: as we saw in Table 1, Hana's linguistic self-confidence rose by one point (raw score). We also cannot consider Dörnyei and Taguchi's scale to be a measure of confidence in L2 communicative ability because Dörnyei and Taguchi's scale measures student evaluations of their future L2 competence in reading and writing, both referred to in scale items, but competence in speaking and listening are not part of the scale. In my own previous studies, the L2MSS linguistic self-confidence measure was one of four measures that predicted intended learning effort in first-year Japanese engineering majors (Claro, 2016) but it did not have a significant correlation with intended learning effort at T1 or T2 in the smaller sample of Japanese engineering majors I studied in Claro (2021), the same sample that Hana and Taka were part of.

In contrast, Clément and Kruidenier's (1985) Self-confidence subscale (one of three subscales in the Self-confidence with English scale) is closely linked to self-efficacy in L2 communication because it measures communicative competence as the student's (present) confidence in their perceived capacity to interact appropriately with anglophones on a personal level. Dörnyei (1998) and Irie (2005) both point to Clément and Kruidenier's scale as a measure of expectancy similar to self-efficacy.

Anxiety, a measure related to stress that is found in the L2MSS questionnaire, has also received a lot of attention in L2 motivation studies (see review in Maclntyre \& Gardner, 1991). While stress and anxiety are related, they are different constructs. In self-relevant situations, the balance of primary appraisals (stressor demands) and secondary appraisals (personal coping resources) determines whether the situation is appraised as a threat or a challenge. This is unique to 
Lazarus and Folkman's (1984) transactional theory of stress and coping and has not been considered in L2 motivation studies. As stress is the construct that has been investigated in relation to threat and challenge in mainstream psychology, stress is the construct used in the current article. In my previous studies (Claro, 2016, 2021), the L2MSS anxiety construct did not have a significant correlation with intended learning effort in this population.

However, possible relationships between L2 self-confidence and self-efficacy as resources, and between anxiety and stress as stressor demands, are intriguing. Future studies could measure present self-confidence in L2 communicative ability as well as present anxiety and evaluate the balance of resources to stressor demands (Tomaka et al., 1993) to see if challenge and threat evaluations emerge in ways similar to those described in this article.

\section{Appendix B: Data Elicitation Materials}

\section{Questionnaire}

Dörnyei and Taguchi's (2010) L2 Motivational Self System (L2MSS) instrument (Japanese version) was used in this study. See pages 139-148 for scales, pages 150-153 for the English versions of the items, and pages 154-157 for the Japanese versions of the items.

\section{Interview Questions}

The main interview questions were written in Japanese and English and were given to students before the interview started. There were three main kinds of questions:

1. Interview questions were designed to explore the student learning experience in the ICE Project. For example, the first questions I asked were, "How was the ICE project? What did you think about it?" and "Please tell me about your experience in the ICE project." Based on the student's reply, I asked related follow-up questions.

2. I designed questions to explore some main L2 motivation constructs found in the L2MSS such as integrativeness, the ideal L2 self, attitudes toward learning English and linguistic self-confidence. For example:

Please imagine your "ideal self" in the future, the person you hope to become. Is English ability a part of your "ideal self"? How did you feel about your ability to communicate in English before the ICE project?

3. I also included items taken directly from the L2MSS questionnaire and asked students to first choose their answer from the Likert scale and then explain in detail. For example, for the ideal L2 self, these items from the scale were rated by the student and then explained:

I can imagine myself living abroad and having a discussion in English.

I see myself as someone who is able to speak English. 


\section{Appendix C}

Figure 1. Pre- and Post-project L2 Self Images

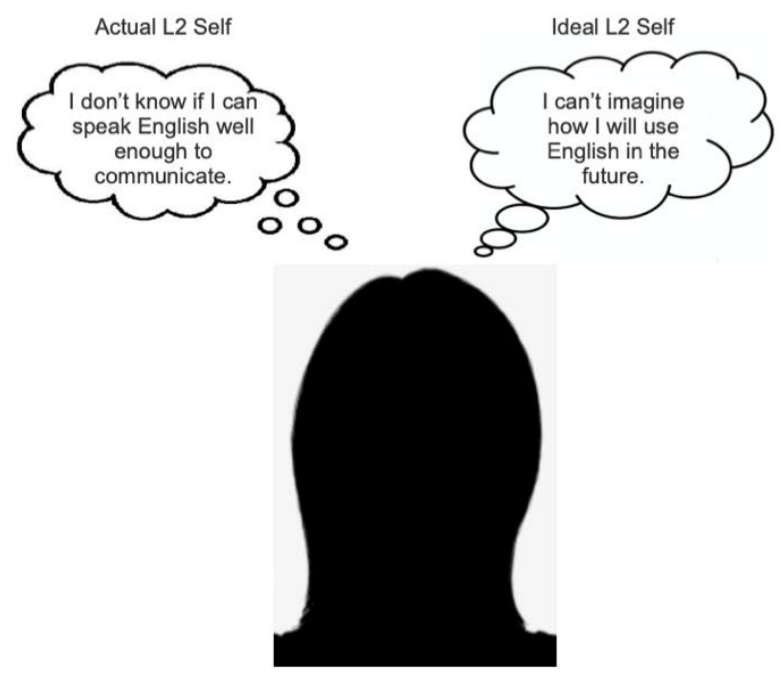

Pre-project:

Vague L2 self images

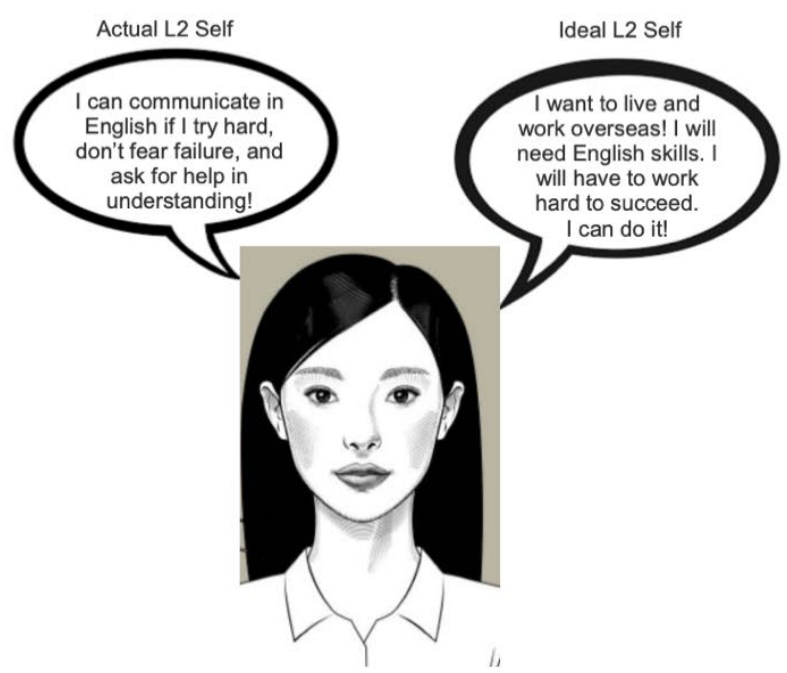

Post-project:

Clear L2 self images

Note. Images and quotations are fictitious. 